\title{
The use of enzyme preparations for pectin extraction from potato pulp
}

\author{
Olena Hrabovska ${ }^{1}$, Hanna Pastukh ${ }^{1}$, Oleksandr Lysyi ${ }^{1}$, \\ Volodymyr Miroshnyk ${ }^{2}$, Nadiya Shtangeeva ${ }^{1}$
}

\section{1 - National University of Food Technologies, Kyiv, Ukraine \\ 2 - National University of Bioresources and Nature Management, Kyiv, Ukraine}

Keywords:
Potato
Pulp
Pectin
a-amylase,
Hydrolysis
Cellulase

Article history:

Received

26.04.2018

Received in revised form 12.06.2018

Accepted 29.06.2018

Corresponding author:

Olena Hrabovska

E-mail:

helengrabovski@ ukr.net

DOI:

$10.24263 / 2304-$

974X-2018-7-2-5

\section{Abstract}

Introduction. The use of enzyme preparations at various stages of the technological process of extracting pectin from potato pulp and their influence on yield and purity of pectin has been studied.

Materials and methods. The hydrolysis of potato pulp's protopectin was carried out in various ways using hydrochloric acid, enzymatic preparations of cellulolytic and amylolytic activity at different stages of the technological process and in a combined method.

Results and discussion. The effect of a complex enzyme preparation of cellulase on the final produce yield and quality has been researched. It was stated that adding the enzyme preparation at the stage of preliminary treatment of raw materials in an amount of $0,1 \%$ of the total dry matter mass (accordingly $9 \mathrm{CU} / \mathrm{g}$ of raw material) in combination with acid-thermal hydrolysis leads to an increase in the recovery of alcohol-sugared potato pectin from $7 \%$ to $13,6 \%$.

The positive influence of amylolytic enzyme preparations on the physical and chemical properties of potato pectin has been proved. Dosage of the enzyme was carried out in the amount of $3 \mathrm{AU} / \mathrm{g}$ of absolutely dry starch. The use of amylolytic enzyme preparations in order to process potato pulp in combination with acid hydrolysis raised the uronide component of potato pectin from $27.4 \%$ to $42 \%$.

The study of the structure of potato pectin samples, extracted under different conditions, by comparison of infrared spectra has been carried out. We have used the method of Xray diffraction analysis to investigate changes in the structure of potato pectin obtained by different methods and compared it with potato starch. It is proved that the use of enzymes at the stage of preliminary processing of raw materials increases the yield, purity and complexing ability of pectin.

Conclusions. The use of cellulolytic enzyme preparations and $\alpha$-amylase in the technology of pectin extraction from a potato pulp in combination with acid-thermal hydrolysis leads to an increase in the yield and purity of potato pectin. 


\section{Introduction}

Potatoes are grown in more than 130 countries of the world and ranked fourth in the world in terms of growing (after rice, wheat and corn). The average world annual potato harvest is 367.75 million tons. A large part of the potato is used for the production of potato starch [1], which in turn is widely used in the food and pharmaceutical industries.

Annually the mass of waste products of starch production - potato pulp - only in European countries is more than 1 million tons [2, 3], including about 40 thousand tons in Ukraine. Basically, these wastes are fed to cattle [2], but they may be an industrial source of such a valuable nutritional supplement as pectin.

One can trace investigations on the use of potato pulp as a source of bioethanol $[4,5]$, edible fibers [2, 6-8], alcohol [9] and pectin [10-15].

Potato pulp consists mainly of four types of polysaccharides: starch, cellulose, hemicellulose and pectin. Depending on the regulation of the technological process with potato pulp, three target products for the food industry can be obtained: pectin with starch, pectin and fiber. It is known from literary sources that potato pulp contains from $15 \%$ to $30 \%$ of pectin substances and is considered to be a potentially new raw material for their obtaining [7, 8, 16-19].

Pectic polysaccharides, which are the main polysaccharides of potato cell walls, have a unique structure [20], they are mostly rich in ramnogalacturonan I [18, 19] (RG I, 75\%) and homogalacturonan (HG, 20\%) [20].

Methods of pectin extraction from potato pulp by using chelating agent $[12,21]$, in an acidic or alkaline medium, using enzymes and under pressure [15] are currently known. To reduce the starch content, the raw materials are pre-treated with amylolytic enzyme preparations.

Potato pulp contains a large amount of "bound" starch. During the process of protopectin hydrolysis, the starch is partially hydrolyzed to dextrin, and passes into the extract. While coagulating pectin with ethyl alcohol, high molecular weight dextrins are also precipitated, thereby affecting the properties of pectin. A lot of scientific papers are dedicated to the optimal parameters of enzymatic hydrolysis of potato pulp $[2,5,22]$. The enzyme processing is carried out during the preliminary processing of raw materials / or after separation of the extract obtained.

The technology of potato pectin extraction has not yet been sufficiently investigated and studied for its industrial implementation in comparison with the technology of citrus, apple and beet pectin. Potato pulp is not currently used in industry to manufacture commercial pectin, although it meets all the requirements and has a high content of pectin [19].

The purpose of the research is to study the methods of pectin extraction using enzyme preparations and determining their effect on the yield and physical and chemical properties of potato pectin.

\section{Materials and methods}

\section{Chemical reagents and enzymes}

Apple, beet and citrus pectins were extracted in laboratory conditions by means of acid-thermal hydrolysis of raw materials by the methods.

Arabinoza, xylose, glucose, rhamnose, galactose, mannose, potato starch.

$\alpha$-amylase BAN-480L (Novozymes), glucoamylase Optidex-400L (GENENCOR), complex enzyme preparation of cellulolytic action "Cellulade" (Enzyme). 


\section{Pectin extraction}

Pectin extraction was carried out by implementation of successive technological stages of hydrolysis-extraction, separation of pectin extract, neutralization, coagulation of pectin with ethanol, fixation of coagulum, drying and grinding of the finished pectin.

To study the process of hydrolysis, the accuracy of the hydrolysis parameters was the determining factor: $\mathrm{pH}$, temperature, and the duration of the process.

Sample 1. Potato pulp was mixed with an acid solution, preheated to a hydrolysis temperature. The concentration of the acid solution, as a hydrolytic factor, was calculated depending on the set $\mathrm{pH}$ value of the hydrolysis mixture and taking into account the hydrolysis hydromodule. The hydrolysis hydromodule $\left(\mathrm{q}_{\mathrm{r}}\right)$, which is determined by the ratio of the mass of the acid solution to the mass taken on the hydrolysis of the potato raw material, is given equal to 2 (the ratio of pulp raw material (RM): water as 1:10).

Acid-thermal hydrolysis-extraction of potato pulp was carried out using chloride acid at a temperature of $72-75{ }^{\circ} \mathrm{C}, \mathrm{pH}$ of a hydrolysis mixture of $1.3-1.6(1,45 \% \mathrm{HCl}$ to a hydrolysis mass) for 70 minutes. The liquid phase was separated, neutralized with $\mathrm{NH}_{4} \mathrm{OH}$ solution to a $\mathrm{pH}$ of $3-4$. Pectin coagulation was carried out by means of ethyl alcohol $(80 \%)$ at a ratio of extract: ethanol as $1: 2$. Separated pectin coagulate was further washed (fixed) with $96 \%$ ethanol, after which it was dehydrated, dried, ground and sifted.

Sample 2. Pectin, obtained from potato pulp, which had previously been subjected to processing with enzyme preparations of $\alpha$-amylase and glucoamylase followed by acidthermal hydrolysis of the raw material. Processing of raw materials of $\alpha$-amylase enzyme preparation (EP) "BAN 480L" was carried out at a temperature of $72-75^{\circ} \mathrm{C}, \mathrm{pH} 6.0$ adding $\mathrm{EP}$ in the amount of $3 \mathrm{AU} / \mathrm{g}$ of raw material for 30-40 minutes. To inhibit this EP, the mixture was boiled for 3 minutes, after which it was cooled to $50{ }^{\circ} \mathrm{C}$ and the EP of the glucoamylase "Diazyme SG" was added in an amount of 3 units of activity/g of RM. Processing was carried out at $50{ }^{\circ} \mathrm{C}$., $\mathrm{pH} 4.0-4.5$ for 6 hours. After this $\mathrm{HCl}$ solution was added and acid-thermal hydrolysis, extract separation, neutralization and coagulation of pectin was carried out, as described in the method of sample №1 obtaining.

Sample 3. The potato pectin powder obtained by the method of acid hydrolysis described above (sample №1) was dissolved in water and processed with EP amylolytic action: $\alpha$-amylase and glucoamylase as described in the method of sample №2 obtaining. At the same time, during the whole time of enzymatic hydrolysis, samples of a qualitative reaction on starch with iodine were made. Upon completion of enzyme processing, pectin was again precipitated with ethanol as described above (see sample №1).

Sample 4. Potato pectin is obtained from the raw material of preliminary processed cellulase and $\alpha$-amylase enzyme preparation followed by acid-thermal hydrolysis. Enzyme preparation processing "Cellulad" was carried out in the amount of $9 \mathrm{CU} / \mathrm{g}$ (cellulose units per gram) of raw material $\mathrm{pH} 5.5-6.5$, temperature $50{ }^{\circ} \mathrm{C}$ for 3 hours. After that the hydrolysis mass of the $\alpha$-amylase enzyme preparation "BAN 480L" in the amount of 3 AU/g (amylase units per gram) of raw material was added and processed at a temperature of $72-75{ }^{\circ} \mathrm{C}$., $\mathrm{pH} 6.0$ for $30-40$ minutes. Acid-thermal hydrolysis of the mixture and subsequent pectin extraction operations were carried out as indicated in the method of sample №1 obtaining.

Sample 5. Potato pectin obtained by preliminary processing of pulp of cellulose enzyme preparation in the amount of $9 \mathrm{CU} / \mathrm{g}$ of raw material at $\mathrm{pH} 5.5-6.5$, temperature 50 ${ }^{\circ} \mathrm{C}$ for 3 hours followed by acid-thermal hydrolysis (as in the method of sample №1 obtaining). Separated pectin extract was processed with a $\mathrm{pH}$ of $\alpha$-amylase "BAN 480L" in the amount of $3 \mathrm{AU} / \mathrm{g}$ of raw material at a temperature of $72-75^{\circ} \mathrm{C}, \mathrm{pH} 6.0$ for 30 minutes. 
Pectin coagulation was carried out by means of the method described above (see sample №1).

Sample 6. Potato pectin obtained by means of enzymatic hydrolysis of potato pulp without using acids and other reagents. Enzymic hydrolysis was carried out by EP of cellulolytic action "Cellulad" in the amount of $9 \mathrm{CU} / \mathrm{g}$ of raw material at a temperature of $50{ }^{\circ} \mathrm{C}$, pH 5.5-6.5 for 3 hours. Pectin coagulation was carried out by means of the method described above (see sample №1).

Beet pectin. Fresh beet pulp was extracted with a solution of hydrochloric acid at a 1 : 1 ratio at a temperature of $80-85^{\circ} \mathrm{C}, \mathrm{pH} 0.8-1.0$ for 1 hour.

Pumpkin pectin. Parameters of hydrolysis of pumpkin raw materials were selected on the basis of the study of literary sources: the temperature $70-75^{\circ} \mathrm{C}, \mathrm{pH} 1,6-1,8$; hydrolysis duration -1 hour.

Sunflower pectin. To extract pectin from inflorescences of sunflower baskets, the parameters were used: the ratio of solid and liquid phases as $1: 4$, temperature $80-85^{\circ} \mathrm{C}$, $\mathrm{pH} 0.7$, hydrolysis duration -1 hour.

Citrus pectin. Pectin was extracted from citrus peels dried and milled by a laboratory mill. Parameters of hydrolysis-extraction are as follows: raw material ratio: extractant as $1: 10$, temperature $90-92{ }^{\circ} \mathrm{C}, \mathrm{pH} 1,0-1,2$, duration of the process $30-40 \mathrm{~min}$.

Apple pectin. Apple pectin was extracted from fresh apple marc at a temperature of $80{ }^{\circ} \mathrm{C}, \mathrm{pH} 1.6$ for 1 hour.

Pectin extract coagulation, coagulate consolidation and drying was performed as described for sample 1 .

\section{Physical and chemical properties of potato pectin}

The content of ballast substances in dry potato pectin was investigated by weight method. Analytical characteristics: the content of methoxyl, carboxyl groups, the uronide component - by titerometric method, the complexing ability, respectively [23].

\section{Investigation of sorption ability}

The sorption properties were determined on a McBen sorption-vacuum unit, where on previously dehydrated samples at temperature of $20^{\circ} \mathrm{C}$ and pressure of 0 to $18 \mathrm{Mmhg}$ the sorption of water vapor was carried out until a hygroscopic state was achieved. After that, desorption was performed in equilibrium conditions. To evaluate the sorption characteristics of pectin, a method of constructing sorption-desorption isotherms was used. A study of the sorption characteristics was carried out for five samples of potato pectin (numeration of samples according to the preliminary subparagraphs).

Isotherms of adsorption-desorption of water vapor of potato pectin were determined as the ratio of partial pressure of water vapor above the surface of the sample to the partial pressure of a saturated vapor of pure water.

$$
a_{w}=P / P s
$$

To confirm the model of water adsorption by hydrocolloids, the first portion of the adsorption curve is represented in linear coordinates $(P / P s) / a=f(P / P s)$ through the Langmuir equation:

$$
a=a_{m} B(P / P s) /(1+B(P / P s))
$$


where $a$ is the amount of substance that is adsorbed at a certain activity of water; $a_{m}$ - the amount of adsorbed material required to cover the surface with a dense monomolecular layer; $B$ - a constant characterizing the energy of the interaction of the adsorbate and the adsorbent (the energy of adsorption); P/Ps - relative equilibrium pressure of water vapor. The value of the capacity of the monomolecular layer $\left(a_{m}\right)$ was found for the studied samples of potato pectin as a catagan of the angle of inclination of the straight line to the abscissa axis, $a_{m}=\operatorname{ctg} a$.

To describe and analyze this zone, we used the Freundlich empirical equation:

$$
A=\frac{a}{m}=k \cdot p^{\frac{1}{n}}
$$

where $a$ is the amount of adsorbed substance; $m$ - mass of adsorbent; $p$ - equilibrium gas pressure in the system; $1 / n$ - characterizes the intensity of adsorption; $k$-constant.

For the convenience of experimental data processing, the logarithmic form of this equation is used:

$$
\lg a=\lg k+\frac{1}{n} \lg p
$$

\section{IR spectroscopy}

Investigation of the monosaccharide composition of potato pectin was carried out using IR spectroscopy. Infrared spectra are recorded in the range of $400-4000 \mathrm{~cm}^{-1}$ on the Fourier spectrometer of FT-IR Spectrum BX-II, Perkin Elmer. Samples were prepared in the form of $\mathrm{KBr}$ tablets.

\section{X-ray diffraction spectrometry}

The phase structure of pectin samples was studied by using X-ray method. The diffraction curves were recorded in "reflection" mode on an X-ray diffractometer HZG4A (Carl Zeiss, Jena, Germany) using copper $\left(\mathrm{CuK}_{\alpha}\right)$ radiation, nickel-filtered.

\section{Electronic scanning microscopy}

Electronic micrographs are made using a scanning electron microscope LEO 1420 (Germany).

\section{Results and discussion}

\section{Influence of cellulase concentration on the yield of potato pectin}

It is known that even under harsh conditions of hydrolysis of plant raw material (low $\mathrm{pH}$, high temperature), the process of hydrolysis of protopectin is incomplete. In order to increase the yield of pectin, the enzyme preparation of cellulolytic action was used at the stage of preliminary processing.

In order to increase the yield of pectic substances of potato raw materials, the domestic complex enzyme preparation "Celulad" was used, with an activity of 9,000 CU/g ("Enzyme"). 
In the process of preliminary processing, the enzyme was added in an amount of $0.1 \%$, $0.5 \%, 1 \%$ to the RM mass $(9,45,90 \mathrm{CU} / \mathrm{g}$ of raw material, respectively). Enzymatic hydrolysis was carried out for 3 hours at a temperature of $50{ }^{\circ} \mathrm{C}$ at a hydromodule of $1: 2$. After that, acid-thermal hydrolysis with chloride acid was carried out under optimal conditions: $\mathrm{pH} 1.6$, temperature $72-75{ }^{\circ} \mathrm{C}$, duration $70-75$ min [33]. Also, pectin sample was obtained by using enzymes only $(0.1 \% / 9 \mathrm{CU} / \mathrm{g}$ of raw material). The results of research on the pectin yield are presented in Figure 1.

Pectin was used as the comparison sample, removed by acid-thermal hydrolysis of the raw material under similar conditions without adding enzymes (Figure 1, control).

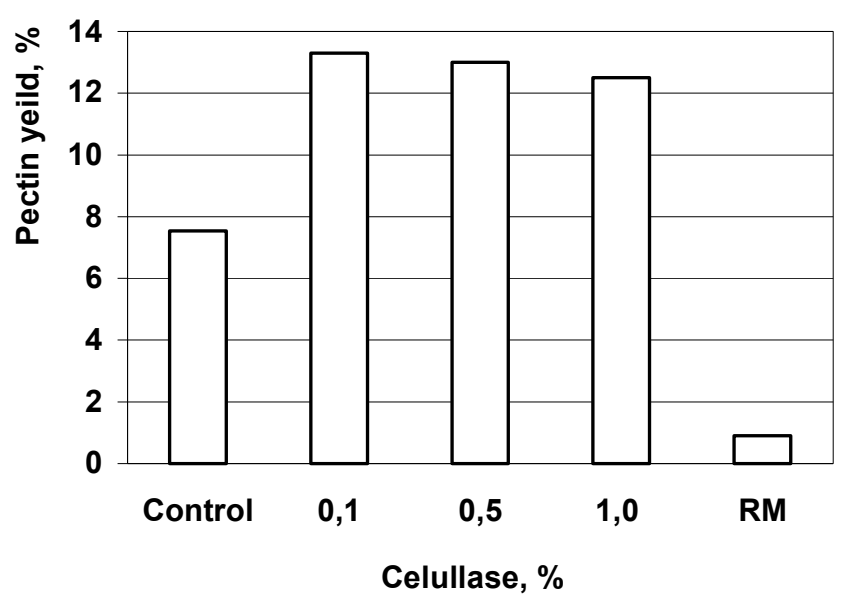

Figure 1. Dependence of the pectin yield on the enzyme concentration

Processing of potato pulp by cellulase leads to a significant increase in the yield of pectin, namely while adding EP in the amount of $0.1 \%$ in combination with acid-thermal hydrolysis, the yield is increased almost twice (from 7.54\% to 13.3\%). With a further increase in the amount of added enzyme preparation, there is no significant decrease in the pectin yield, and the use of only cellulases in the amount of $0.1 \%$ ( $9 \mathrm{CU} / \mathrm{g}$ of raw material) does not provide high results. Thus, the use of cellulolytic enzyme preparations at the stage of preliminary processing of plant raw materials in combination with acid-thermal hydrolysis allows a significant increase in the yield of pectin substances.

In order to obtain a pectin sample extracted without using acid and any other chemical reagents, we conducted a series of experiments using cellulase enzyme preparation to hydrolyze potato pulp (Figure 2). EP was added in the amount of 9, 18, 27, $36 \mathrm{CU} / \mathrm{g}$ of raw material.

The highest pectin yield (5.11\%) was observed while using EP in the amount of 36 $\mathrm{CU} / \mathrm{g}$ of raw material. It should be noted that despite the high yield of pectin substances in enzymatic hydrolysis, its coagulation structure is weak. 


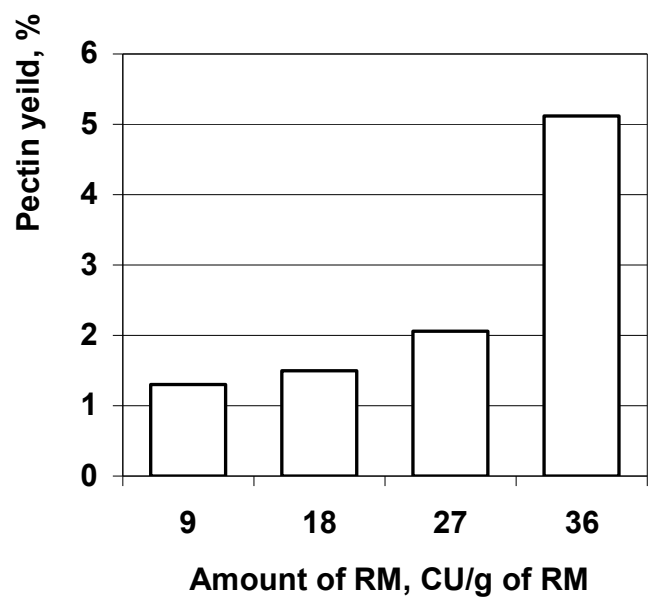

Figure 2. Pectin yield (\% to the RM mass), depending on the dosage of cellulase enzyme preparation (CU/g of raw material)

Thus, on the basis of experimental researches it was established that the most effective use is the use of enzyme preparations of cellulase at the stage of preliminary processing of raw materials in the amount of $0.1 \%$ to the mass of RM under the conditions of enzymatic processing: $\mathrm{pH}$ 5.5-6.5, temperature $50{ }^{\circ} \mathrm{C}$, duration 3 hours followed by acid-thermal hydrolysis of raw materials.

\section{Influence of $\alpha$-amylase enzyme preparation on pectin extraction from potato pulp}

Using qualitative reaction to starch, it was found that the obtained potato pectin samples contain a certain amount of starch, which in a partially hydrolyzed state passes into the extract from the pulp and precipitates with ethanol. This is indicated by a blue color when adding an iodine solution to the obtained dry pectin sample.

In order to improve the pectin purity, we conducted a series of experimental studies on the methods of pectin extracting using amylolytic enzymes at different stages of the process, namely: use of $\alpha$-amylase (AM) at the stage of preliminary processing of potato raw material (sample 4) and processing of the resulting pectin extract (PE) after acidthermal hydrolysis (sample 5).

The bacterial $\alpha$-amylase BAN-480L, with an activity of $1000 \mathrm{AU} / \mathrm{g}$, was used for the research. Enzymatic hydrolysis of the pulp (sample 4) with this enzyme preparation was carried out at a temperature of $75^{\circ} \mathrm{C}$ and a pH of the hydrolysis mass of 5.5-6.0, based on the specification of this EP. Dosage of the enzyme was carried out in the amount of $3 \mathrm{CU} / \mathrm{g}$ of raw material (in terms of starch). Enzymatic hydrolysis with amylase was carried out for 30-40 minutes.

The optimal duration of enzymatic hydrolysis and $\alpha$-amylase enzyme preparation dosage was established by carrying out a series of studies on the accumulation of reducing substances in potato pulp hydrolysates, the concentration of which was determined by the Wiltshtetter and Schudl method. The results of the studies are presented in Table 1. 
Table 1

The content of reducing saccharides (in terms of glucose) in the hydrolyzate, depending on the amount of $\alpha$-amylase added

\begin{tabular}{|c|c|c|c|}
\hline $\begin{array}{c}\text { Dosage of enzyme } \\
\text { (amount of CU/g of } \\
\text { raw material) }\end{array}$ & $\begin{array}{c}\text { Hydrolysis } \\
\text { duration, hour }\end{array}$ & $\begin{array}{c}\text { Amount of glucose in } \\
\text { the extractor, } \mathbf{g}\end{array}$ & $\begin{array}{c}\text { Glucose mass } \\
\text { fraction, \% }\end{array}$ \\
\hline 3,0 & 0,5 & $0,447 \pm 0,01$ & 4,47 \\
\hline 3,0 & 1,0 & $0,458 \pm 0,01$ & 4,58 \\
\hline 3,0 & 1,5 & $0,458 \pm 0,01$ & 4,58 \\
\hline 2,0 & 0,5 & $0,330 \pm 0,02$ & 3,30 \\
\hline 2,0 & 1,0 & $0,370 \pm 0,01$ & 3,70 \\
\hline 2,0 & 1,5 & $0,380 \pm 0,01$ & 3,80 \\
\hline 1,5 & 0,5 & $0,240 \pm 0,02$ & 2,40 \\
\hline 1,5 & 1,0 & $0,340 \pm 0,01$ & 3,40 \\
\hline 1,5 & 1,5 & $0,320 \pm 0,01$ & 3,20 \\
\hline 1,0 & 0,5 & $0,360 \pm 0,02$ & 3,60 \\
\hline 1,0 & 1,0 & $0,340 \pm 0,01$ & 3,40 \\
\hline 1,0 & 1,5 & $0,370 \pm 0,01$ & 3,70 \\
\hline
\end{tabular}

The dosage range of AM EP was chosen regarding previous studies. In addition, experiments were carried out with adding AM EP in the amount of AU/g of raw material, which showed that an increase in the number of enzyme preparation does not give high values - the glucose content was $4.16 \%$ to RM. While adding AM EP in the amount of 0,75 $\mathrm{AU} / \mathrm{g}$ of raw material and $0.5 \mathrm{AU} / \mathrm{g}$ of raw material, glucose content in the hydrolyzates was $1.2 \%$ and $0.8 \%$, respectively, indicating insufficient starch breakdown and is not effective.

Thus, enzymatic hydrolysis of potato pulp of $\alpha$-amylase enzyme preparation should be carried out at a temperature of $75^{\circ} \mathrm{C}, \mathrm{pH}$ of a hydrolysis mass of 6.0 , the EM dosage 3 $\mathrm{AU} / \mathrm{g}$ of raw material for 30-40 minutes. An analysis of potato pulp micrographs of preliminary processed with amylolytic EP and without such processing, made using a scanning electron microscope on the content of starch grains (Figure 3) was carried out. Thus, in potato pulp, when using AM EP at the stage of preliminary processing of raw materials (Figure 3, c), there are no clearly expressed grains of starch in the field of view of the microscope comparing with the pulp, which was subjected to acid-thermal hydrolysis (Figure 3, b), grains of starch are outlined in the image. It should be noted that even under aggressive hydrolysis conditions, starch grains remain in the potato raw material. In the microphotography there is a significant amount of starch grains, which under these hydrolysis conditions are only partially hydrolyzed to dextrins and precipitated with ethanol. In the microphotography (Figure 3, a) of potato pulp, taken after the technological process of starch extraction, the starch grains are clearly visible among fiber particles. After enzymatic hydrolysis by $\alpha$-amylase, the pulp does not actually contain starch grains (Figure $3, c)$, which confirms the effectiveness of the $\alpha$-amylase preparations use for potato pulp preliminary processing before acid-thermal hydrolysis. 


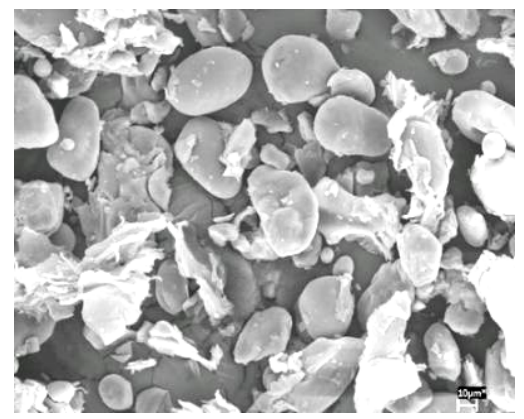

$\mathbf{a}$

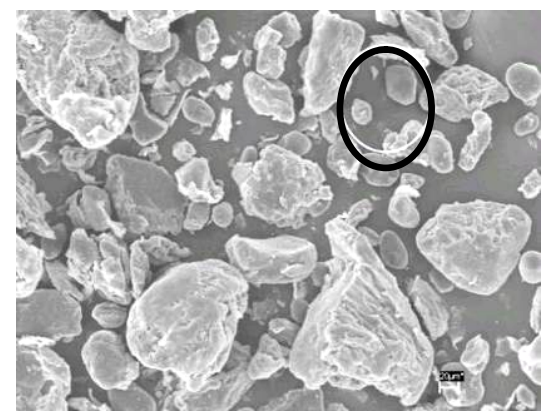

b

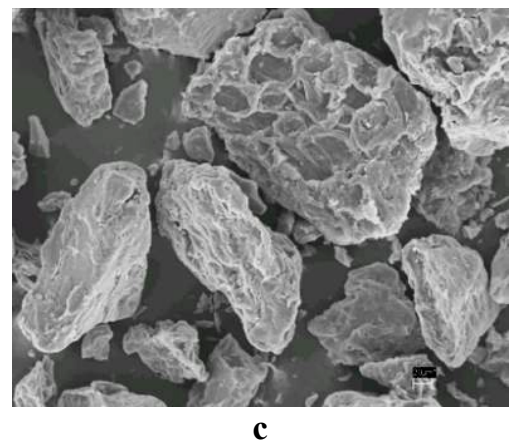

Figure 3. Electronic scanning microphotography of potato pulp: a - after starch extraction ( $10 \mathrm{~nm}$ resolution); $\mathrm{b}$ - after acid-thermal hydrolysis (20 nm resolution); $\mathrm{c}-$ after the enzymatic hydrolysis of AM EP (20 nm resolution)

Enzymic processing of pectin extract (sample 5) was carried out after acid-thermal hydrolysis of raw materials, according to the following parameters: temperature $-75{ }^{\circ} \mathrm{C}$, EP dosage $-3 \mathrm{AU} / \mathrm{g}$ of raw material, duration -30 minutes, $\mathrm{pH}$ of the extract $-3-4$. The extract neutralization to the $\mathrm{pH}$ value of 5.5-6.0 leads to deterioration of the final product quality - potato pectin. The potato pectin obtained in this way has better physicochemical parameters than potato pectin obtained only by acid-thermal hydrolysis, but somewhat worse than the pectin obtained in the above-described method (sample 4).

\section{Physical and chemical properties of potato pectin, extracted under different technological conditions}

Spheres of pectin use depend on its physical and chemical properties, namely, the content of the uronide component and the degree of esterification. These two indicators make it possible to recommend pectin to be used as a gelatinizer or stabilizer in the food industry, or as an enterosorbent in medicine. Pectin physicochemical properties to a large extent depend on the technological parameters of the basic processes - raw materials hydrolysis and pectin extraction. We obtained a number of potato pectin samples and determined their physical and chemical indices. Table 2 shows the most characteristic samples obtained by acid hydrolysis (Table 2, sample 1); combined hydrolysis involving enzyme preparations of cellulolytic and amylolytic action, and then chloride acid (Table 2, sample 4); combined hydrolysis with enzymatic preparations of cellulolytic action, then 
hydrochloric acid followed by processing of the obtained extract with $\alpha$-amylase (Table 2 , sample 5); hydrolysis using only enzymatic preparations of cellulolytic and amylolytic action (Table 2, sample 5). Physico-chemical parameters of potato pectin samples obtained under different conditions are given in Table 2 (for the description of the methods for obtaining samples, see the section "Methods and Materials").

Potato pectin physico-chemical parameters

Table 2

\begin{tabular}{|l|c|c|c|c|}
\hline \multicolumn{1}{|c|}{ Indices } & Sample 1 & Sample 4 & Sample 5 & Sample 6 \\
\hline Ash content, \% & $1,20 \pm 0,1$ & $2,40 \pm 0,1$ & $1,40 \pm 0,1$ & $0,95 \pm 0,1$ \\
\hline $\mathrm{pH}$ 1\% solution of pectin & $2,94 \pm 0,2$ & $3,90 \pm 0,3$ & $3,24 \pm 0,2$ & $4,5 \pm 0,05$ \\
\hline Mass fraction of ballast compounds, \% & $13,30 \pm 0,5$ & $6,70 \pm 0,5$ & $7,28 \pm 0,5$ & $5,43 \pm 0,1$ \\
\hline Content of free carboxyl groups, \% & $0,85 \pm 0,1$ & $5,26 \pm 0,1$ & $4,62 \pm 0,1$ & $4,05 \pm 0,05$ \\
\hline $\begin{array}{l}\text { Content of esterified carboxyl groups, } \\
\%\end{array}$ & $0,72 \pm 0,05$ & $4,80 \pm 0,1$ & $5,65 \pm 0,1$ & $6,75 \pm 0,05$ \\
\hline Uronide component, \% & $27,4 \pm 0,1$ & $41,10 \pm 0,5$ & $42 \pm 0,5$ & $62,5 \pm 0,5$ \\
\hline Esterification degree, \% & $45,86 \pm 0,1$ & $47,70 \pm 0,1$ & $55,0 \pm 0,1$ & $44,5 \pm 0,1$ \\
\hline Complex-forming ability, $\mathrm{Pb}^{2+} \mathrm{mg} / \mathrm{g}$ & $104,0 \pm 0,5$ & $310,0 \pm 0,5$ & $83,0 \pm 0,5$ & $325,0 \pm 0,1$ \\
\hline
\end{tabular}

The use of EP of amilolytic action leads to an increase in the uronide component comparing to the control by 1.5 times, which can be explained by a decrease in the content of starch hydrolysis products in the finished pectin powder.

One of the important properties of pectin substances is the complexing ability, due to which pectin is widely used in medicine, food industry and agriculture. This ability depends on the number of free carboxyl groups, that is, the esterification degree of carboxyl groups with methyl alcohol. The complexing ability also depends on the $\mathrm{pH}$ medium. The ability to form complexes for potato pectin at $\mathrm{pH} 3.9$ (sample 4) is $310 \mathrm{~Pb}^{2+} \mathrm{mg} / \mathrm{g}$. For example, for comparison, the beet pectin complexing ability at $\mathrm{pH} 5.0$ is $505.0 \mathrm{~Pb}^{2+} \mathrm{mg} / \mathrm{g}$, and apple pectin $-312.3 \mathrm{~Pb}^{2+} \mathrm{mg} / \mathrm{g}[15]$.

\section{Potato pectin structure}

Infrared spectra of pectin substances contain information on their composition and structure, purity, absolute and relative number of free and substituted carboxyl groups, and the presence of an ash component [15].

Although the composition and structure of pectin substances has not been fully established, today the monosaccharide composition of some pectins, determined by gasliquid chromatography, is known: beet pectin contains galactose, glucose, arabinose and rhamnose [15]; apple pectin - galactose, glucose, mannose, xylose, arabinose and rhamnose; citrus pectin - galactose, xylose, arabinose and rhamnose [15], potato pectin rhamnose, arabinose, galactose [18, 19, 27].

Pectin properties depend on its chemical composition, the degree of esterification, molecular weight, the ratio of the content of neutral saccharides and the uronide component.

In such a way, the study of the monosaccharide composition of pectin samples is extremely important, since they greatly affect the properties of the polysaccharide, thus defining the scope of its application, and comparing the structure of potato pectin with other 
species makes it possible to evaluate the replacement of expensive imported pectin by domestic one.

Samples of all investigated pectins were extracted in laboratory conditions, in order to avoid the influence of extraneous sugars and stabilizers used in commercial pectin samples.

Spectra of pectin substances have a rather complex structure, therefore we considered only the bands, the identification of which coincides with other studies. Table 4 provides literature data on the position of the functional group peaks and the peaks of the pectin samples under study.

\section{Position of the characteristic bands $\left(\mathrm{cm}^{-1}\right)$ of infrared spectra}

Table 4

\begin{tabular}{|c|c|c|c|c|c|c|}
\hline $\begin{array}{c}\text { Types of } \\
\text { fluctuations }\end{array}$ & $\begin{array}{c}\text { Position of the } \\
\text { characteristic } \\
\text { bands }\end{array}$ & $\begin{array}{c}\text { Sample } \\
\text { № 4 }\end{array}$ & $\begin{array}{c}\text { Sample } \\
\text { №6 }\end{array}$ & Beet & Apple & Citrus \\
\hline \multirow{2}{*}{$v(\mathrm{OH})_{6}$} & $3600-3000$ & 3420 & 3413 & 3433 & 3433 & 3394 \\
\hline $\mathrm{CH}_{2}$ & $2960-2926$ & 2931 & 2925 & 2931 & 2931 & 2938 \\
\hline $\mathrm{C}-\mathrm{H}$ & $3000-2800$ & - & - & - & - & 2899 \\
\hline & & 2364 & - & - & - & 2364 \\
\hline $\mathrm{C}=\mathrm{O}$ & $1750-1350$ & 1739 & 1739 & 1745 & 1745 & 1745 \\
\hline & 1640 & 1635 & 1648 & 1635 & 1635 & 1628 \\
\hline$\delta_{\mathrm{as}}\left[(\mathrm{CH}]_{3}\right)_{\mathrm{E}}$ & 1442 & 1537 & 1537 & 1524 & 1524 & \\
\hline$\delta_{\mathrm{s}}\left[(\mathrm{CH}]_{3}\right)_{\mathrm{E}}$ & 1378 & 1368 & 1433 & 1446 & 1446 & 1446 \\
\hline$\delta(\mathrm{CH})_{\mathrm{K}}$ & 1331 & - & - & - & - & 1322 \\
\hline $\mathrm{C}-\mathrm{O}-\mathrm{C}$ & $1300-1050$ & 1244 & 1257 & 1287 & 1231 & 1231 \\
\hline $\begin{array}{c}(\mathrm{C}-\mathrm{OH})_{\mathrm{C}}, \\
\mathrm{n}(\mathrm{C}-\mathrm{C}, \mathrm{C}-\mathrm{O}) \mathrm{K}\end{array}$ & & 1153 & 1159 & 1153 & 1153 & 1146 \\
\hline
\end{tabular}

All pectin samples (Figure 4) contain bands characteristic of pectin substances. The fluctuations of the $\mathrm{OH}$ group are manifested in the form of a wide band in the range 3200$3400 \mathrm{~cm}^{-1}$, which corresponds to the primary hydroxyl groups. And in citrus pectin intensive peak around $3400 \mathrm{~cm}^{-1}$ passes into a slight shoulder of $3300 \mathrm{~cm}^{-1}$. It should be emphasized that the OH-groups of pectin substances are shifted to the low-frequency area in comparison with the $\mathrm{OH}$-groups of water. This is due to the participation of hydroxyls in the system of H-bonds [28].

The small band (shoulder) in the area of 2700-2500 corresponds to the valence fluctuations of the linked $\mathrm{OH}$ carboxyl group [28]. This shoulder is expressed more clearly in beet, apple and potato biopectin. All samples contain clear band within the limits of $1750-1735 \mathrm{~cm}^{-1}$. The intensity and width of the strips are different for each pectin, which indicates a different degree of esterification. This area is one of the most important in identifying pectin substances. The coefficient of specific carbonyl content of carboxyl groups in a pectin molecule is calculated as the ratio of absorption at $1745 \mathrm{~cm}^{-1}$ (fluctuation of carbonyl carboxyl groups) to absorption at a length of 2940-2926 cm-1 (fluctuation of $\mathrm{CH}_{2}$ ) [29]. The presence of a band in the area of $1640 \mathrm{~cm}^{-1}$ in all samples confirms the presence of ionized carbonyl and carboxyl groups, with the largest number in two samples 
of potato pectin. In the analysis of pectins spectra it can be concluded that they contain a significant amount of polygalacturonic acid (intensive absorption bands in the area of 1010$1150 \mathrm{~cm}^{-1}$ ) [29], and peaks in the area $1200-950 \mathrm{~cm}^{-1}$ correspond to the fluctuations of the skeleton of a molecule.
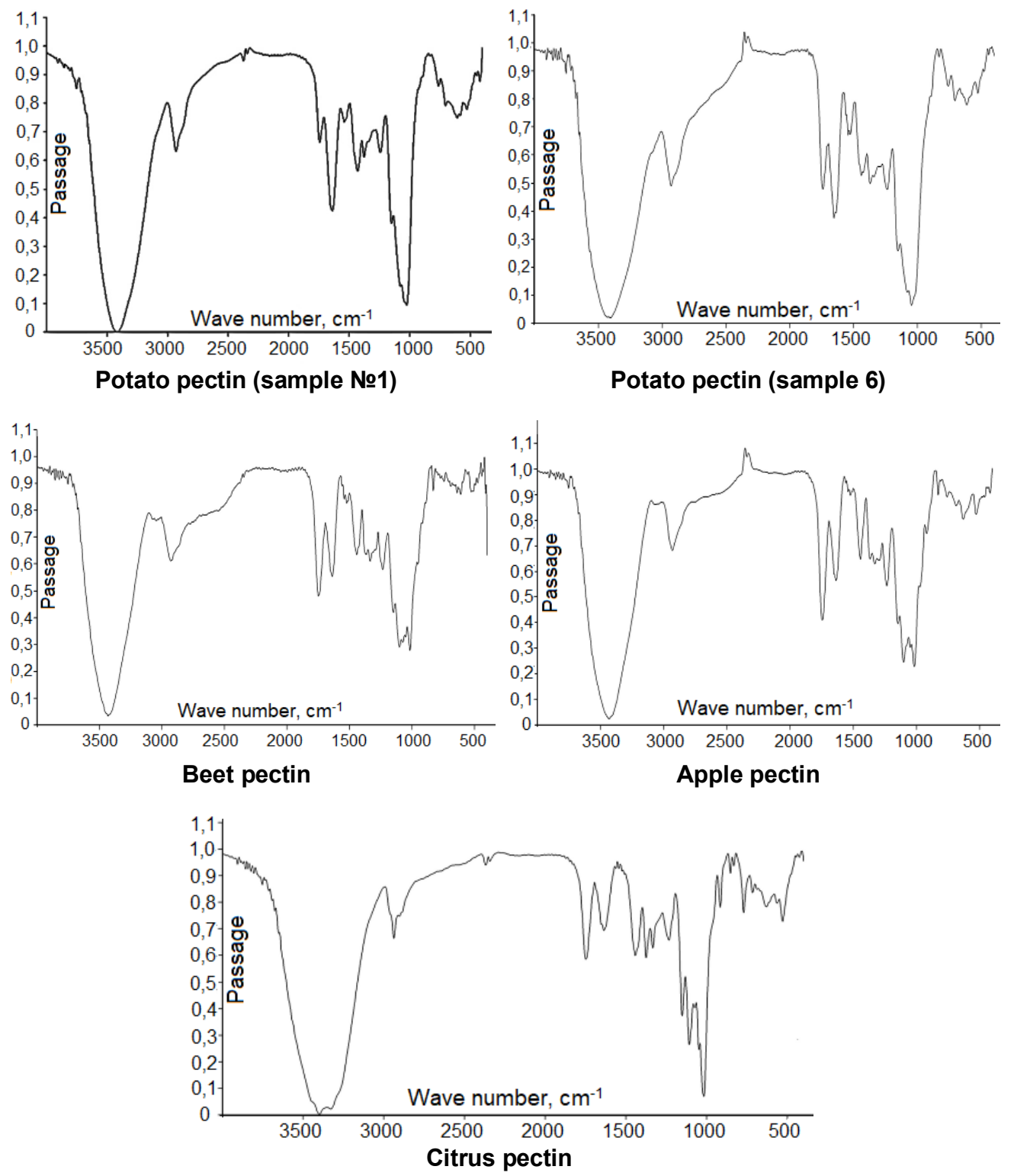

Figure 4. Infrared spectra of different types of pectin 


\section{- Food Technology -}

To distinguish the potato pectin monosaccharide composition, spectral data on monosaccharides were collected: rhamnose, arabinose, galactose, mannose, xylose and glucose. There are no absorption bands characteristic of a particular monosaccharide and inherent only to it. Therefore, in order to identify, by comparing with the spectrum of the known compound, it is necessary to collect the IR spectrum in a wide frequency range, usually from 4000 to $650 \mathrm{~cm}^{-1}$, with a particularly characteristic area of $1250-650 \mathrm{~cm}^{-1}$, the so-called area of fingerprints. The coincidence of the frequency of saccharides fluctuations with the characteristic pectin frequencies at least at three peaks indicates the presence of a pectin molecule in a saccharide [26].

It is known that potato pectin is a rhamnogalakturonan I, which includes rhamnose, galactose, arabinose. This confirms the coincidence of a large number of peaks of these monosaccharides with the characteristic bands of both types of pectin: 3400, 2930, 2365, $1650,1539 \mathrm{~cm}^{-1}$ - with galactose, 1430, 1370 and 1220,1144, 1072, $1036 \mathrm{~cm}^{-1}$ - with rhamnose. Deviation of maximum peaks to $10 \mathrm{~cm}^{-1}$.

However, having analyzed the positions of the maxima of the potato pectin characteristic bands extracted using EP and mannose, it follows that this monosaccharide is also present in a small amount. In particular, it's peaks: $2371,2342,1635,1424,1368$, $1036 \mathrm{~cm}^{-1}$. A slightly smaller amount of peak coincidence in potato pectin extracted by an enzymatic method, with xylose: $1240,1151,1042 \mathrm{~cm}^{-1}$, which suggests that this monosaccharide is also present in a small amount of potato pectin molecules. The presence of xylene may result in reducing the pectin's degradation potential. The presence of a large number of coincident peaks of both pectins with glucose, which can explain the coprecipitation of starch hydrolysis products along with pectin during the process of coagulation with ethanol should be noted.

\section{Method of X-ray diffraction}

In the presence of crystalline formations in a polymer in their spatial lattice, it is possible to detect a large number of different parallel and equidistant mesh planes that cause X-rays diffraction. The diffraction patterns of three potato pectin samples extracted in various ways and potato starch are shown in Figure 5. The obtained diffractograms characterize the relationship between the pulse intensity and the interplanar distances in the structure of the sample [32]. It is known that pectin substances are not characterized by the structure orderliness (crystallinity), therefore the presence of peaks on x-ray films of pectins indicates the presence of residues of starch molecules in the samples.

In the first potato pectin sample, which was extracted without using enzymes, the number of peaks reflection is the largest, indicating a sufficiently high content of starch, which has the crystallinity of a structure of type B, which corresponds to the crystallinity of this pectin sample: $7.52^{\circ}, 13.13^{\circ}, 17,17^{\circ}, 20.17^{\circ}$.

In sample 4 , which was extracted using $\alpha$-amylase, the peak $17.17^{\circ}$, which is characteristic for starch, disappears [32]. The same thing happens in sample 2, that is, when enzymes are used, the number of reflections and, accordingly, the pectin crystallinity decreases due to the hydrolysis of starch co-precipitation, and pectin becomes more amorphous. On the diffractogram of the native potato starch (Figure 5) there are 2 main peaks of reflection: at diffraction angles $2 \theta=17.2$ and 22.2 degrees. In addition to discrete scattering from crystallites, a large fraction of diffuse scattering from the disordered starch phase, that is an amorphous halo, is present on the diffractogram. 

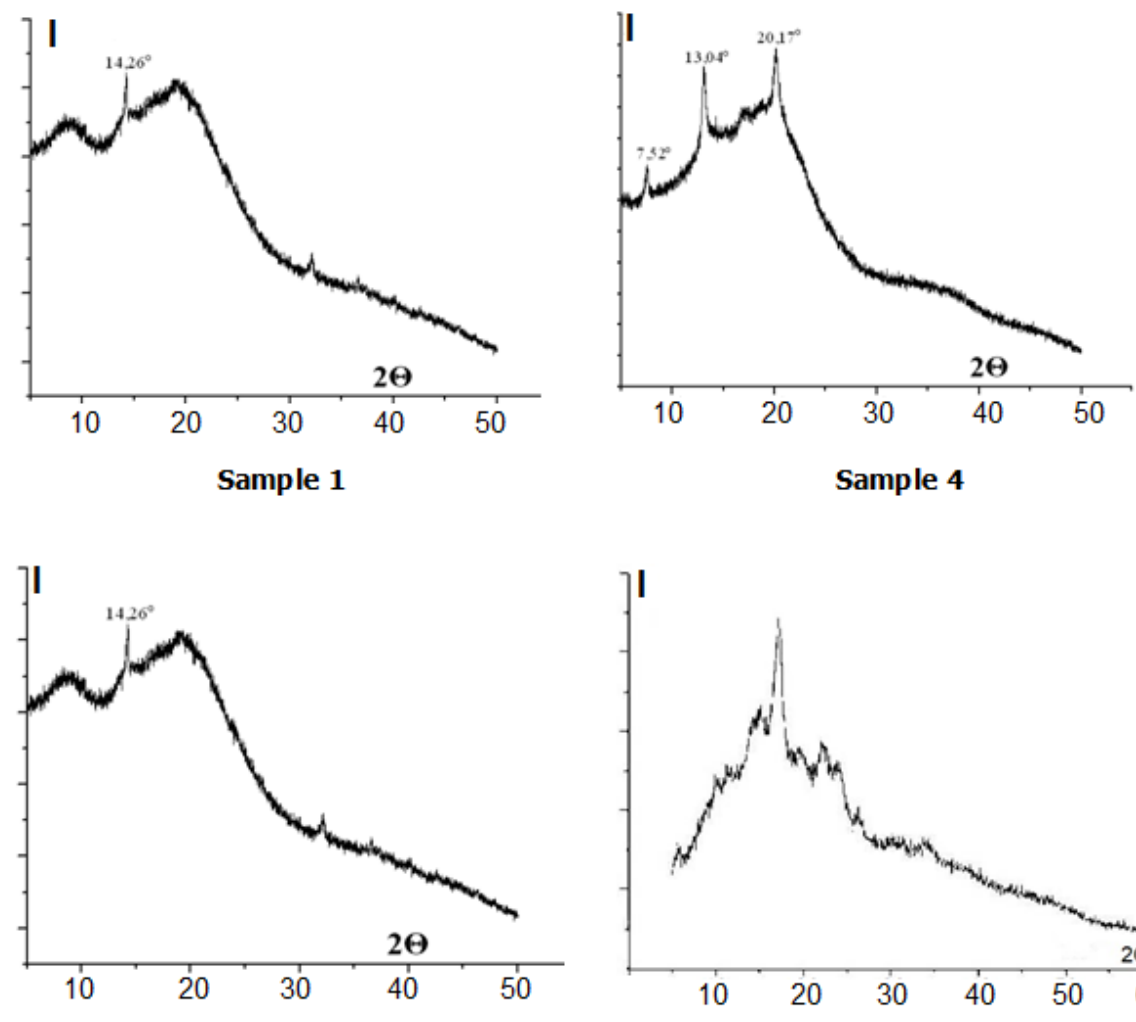

Sample 2

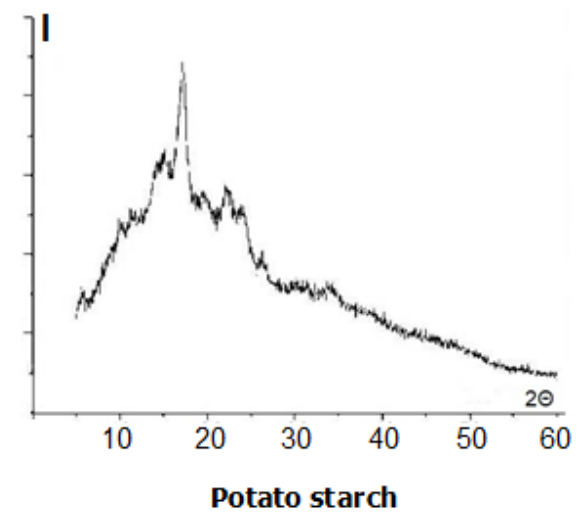

Figure 5. Diffractograms of potato pectin and starch

\section{Sorption-desorption properties of potato pectin obtained in different ways}

Pectin is a natural hydrocoloid, capable of sorbing water in large quantities and swelling with increasing mass. Pectin sorption properties contribute to the manufacture of adsorbents based on it, which are widely used in medicine. Food products enriched with pectin are related to healthy and preventive products. To evaluate the pectin sorption characteristics, a method of constructing isotherms of sorption-desorption is used.

The study of sorption characteristics was carried out for five samples of potato pectin:

1 - obtained by acid-thermal hydrolysis of raw materials;

2 - obtained by acid-thermal hydrolysis of raw materials, preliminary processed with enzyme preparations of amylolytic action ( $\alpha$-amylase + glucoamylase);

3 - pectin, additionally processed with enzyme preparations of amylolytic action;

4 - obtained by acid-thermal hydrolysis of raw materials, preliminary processed with cellulase and $\alpha$-amylase enzyme preparations;

5 - obtained by acid-thermal hydrolysis of raw materials, preliminary processed with cellulase enzyme preparation, and the resulting extract was processed with $\alpha$-amylase.

Pectin sorption properties were investigated by means of a Mac-Ben sorption-vacuum unit, where at $20{ }^{\circ} \mathrm{C}$ and at a pressure from 0 to $18 \mathrm{~mm} \mathrm{Hg}$ sorption of water vapor of pre- 
dehydrated samples were carried out until the hygroscopic state was reached. After that, desorption was performed in equilibrium conditions.

Adsorption isotherms are S-shaped (Figure 6), which is typical for polymolecular adsorption, at which the interaction of water vapor and adsorbent with the formation of polymolecular layers take place. The isotherms of all samples are hysteresis, the emmergence of which indicates that the system under investigation is fine-porous [30]. Isotherms of adsorption-desorption of potato pectin water vapor are shown in Figure 6 in coordinates: the amount of water adsorbed $(a)$ - the water activity $a_{w}$ ), which was defined as the ratio of the partial pressure of water vapor above the surface of the sample to the partial pressure of a saturated vapor of pure water $-a_{w}=P / P s$.

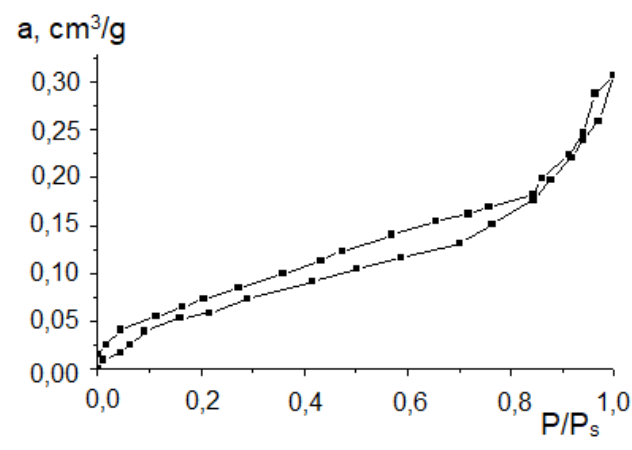

1

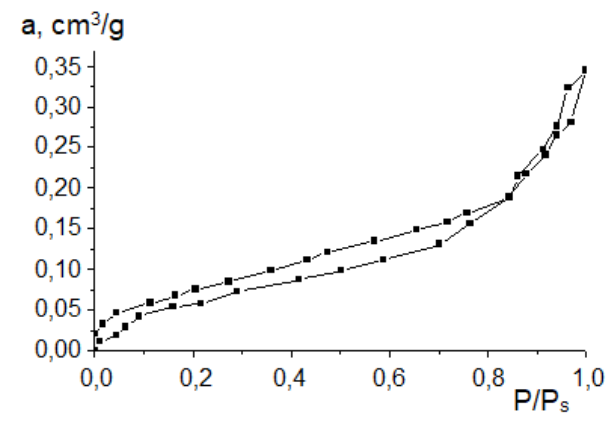

3

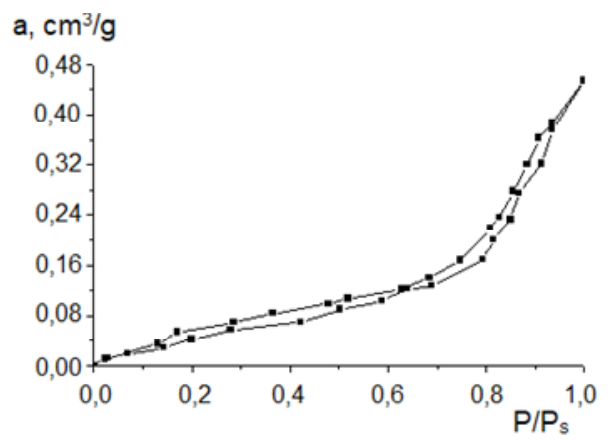

5 a, $\mathrm{cm}^{3} / \mathrm{g}$

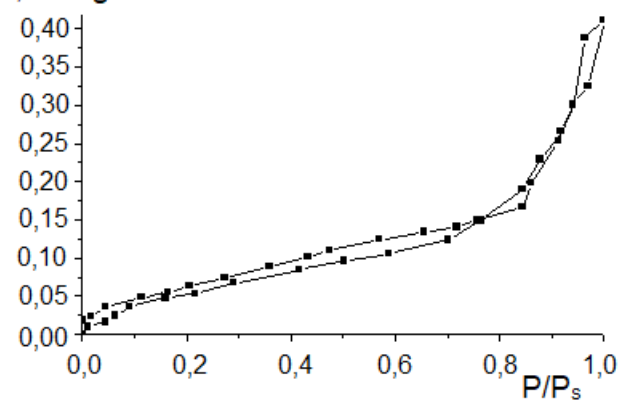

2

a, $\mathrm{cm}^{3} / \mathrm{g}$

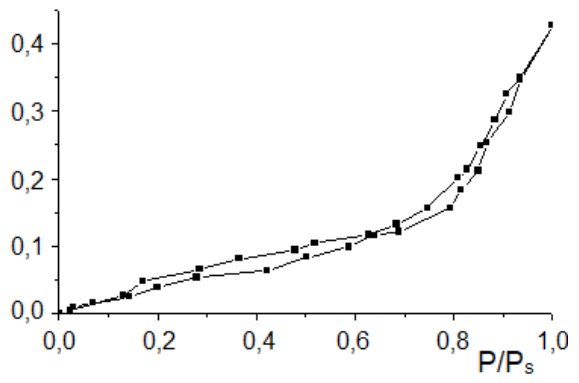

4

Figure 6. Isotherms of adsorption-desorption of potato pectin samples 
Pectin hydration capacity depends on its chemical composition, molecular mass, mutual spatial arrangement of individual chains, dispersion, porosity and other factors. In order to explain the adsorption processes of fine-porous solid adsorbents, the theory of polymolecular adsorption of BET and other scientists is most often used. However, in the case of water vapor adsorption by hydrocolloids, the porous structure is labile (varies in the process of swelling), so the data of the theory cannot be applied [31]. In a detailed analysis of the adsorption isotherms form shown in Figure 6, we can note the wave-like character of the adsorption curves in the pressure range $=0.0-0.9$. The complex nature of the curves can be explained by the gradual development of the Langmuir isotherms of adsorption, which correspond to the formation of the first and second hydrated shells around the active surface pectin centers.

From Figure 6 it is seen that desorption isotherms (dehydration) for all samples are located above adsorption isotherms (moisture). On the graphs of all samples, the hysteresis loopis small in width, but does not end at zero, which is evidence of partial chemisorption, that is, some of the chemically bound water remains in the pectin and is not removed by desorption.

Differential curves of pore distribution by magnitude are presented in Figure 7.

On the graphs of the pores distribution by radius, we see that different types of potato pectin are similar to each other. Micropores, the radius of which is $\leq 20 \mathrm{~A}$ are the most uniformly distributed. Since the size of the micropore is close to the size of the molecules, substances can be adsorbed in the form of individual molecules [30]. All samples in the area up to 10 A have the mostly pronounced peak. However, samples № 4 and № 5 have the largest number of pores of this size. Also, pectins contain mesopores. The diameter of such pores is from 20 to $200 \mathrm{~A}$. It should be noted that these pores play an important role in the adsorption and encapsulation of low-molecular substances, since they can accommodate large molecules while maintaining a high adsorption potential [30]. All pectin samples have no macrospores. To assess the capillary-porous structure of potato pectins, the structural characteristics described in Table 6 were determined.

Table 6

Structural characteristics of potato pectin

\begin{tabular}{|c|c|c|c|c|}
\hline Sample & $\begin{array}{c}\text { Sample specific } \\
\text { surface, } S, \mathrm{~m}^{2} / \mathrm{r}\end{array}$ & $\begin{array}{c}\text { Sorption pores } \\
\text { volume, } V s, \mathrm{~cm}^{3} / \mathrm{g}\end{array}$ & $\begin{array}{c}\text { Sample pores } \\
\text { diameter } D, \mathrm{~A}\end{array}$ & $R^{2}$ \\
\hline 1 & 219 & 0,31 & 57 & 0,9210 \\
\hline 2 & 188 & 0,41 & 87 & 0,9363 \\
\hline 3 & 204 & 0,34 & 67 & 0,9547 \\
\hline 4 & 184 & 0,35 & 76 & 0,8419 \\
\hline 5 & 186 & 0,39 & 84 & 0,9048 \\
\hline
\end{tabular}

Where, $\mathrm{D}$ is the sample pore diameter which is calculated by the formula: $D=4 \mathrm{Vs} / \mathrm{S}$, $A ; R^{2}$ is the square of the calculation error of the sample specific surface.

The obtained data testify that potato pectin is an effective sorbent, and the presence of a large amount of mesopor indicates the possibility of using this pectin as an encapsulating agent for various low molecular weight substances.

Potato pectin, obtained as a result of acid-thermal hydrolysis of potato meats preliminary processed with enzyme preparations has the best sorption properties. 

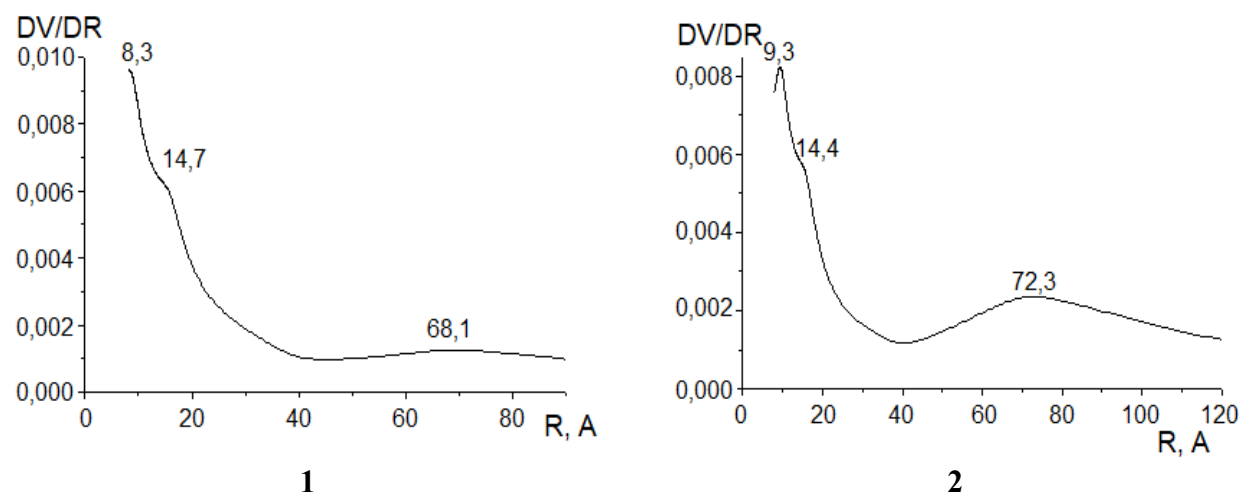

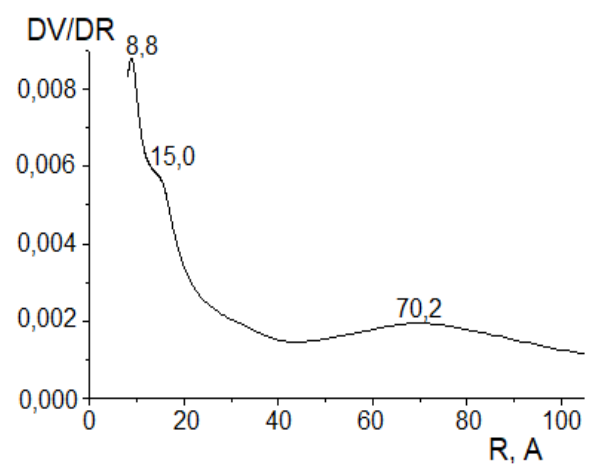

3

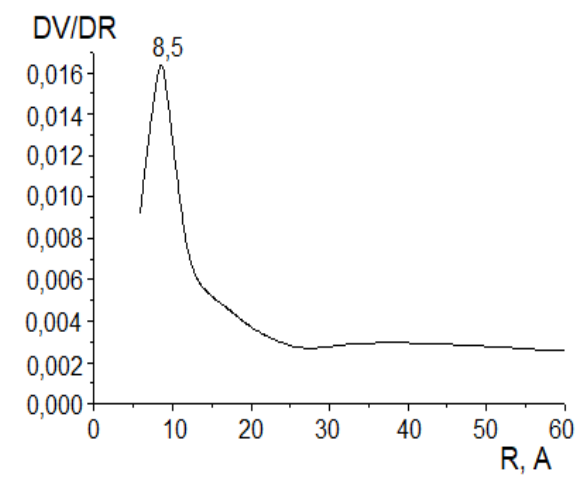

4

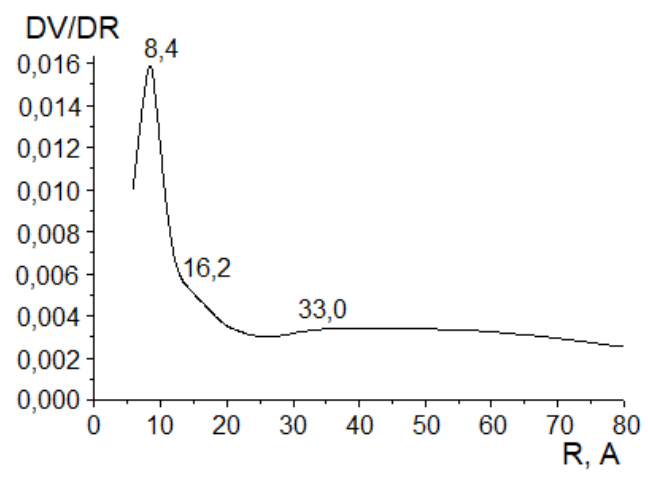

5

Figure 7. Differential curves for pore distribution by radius for different potato pectin samples

\section{Conclusions}

Based on the analysis of the physicochemical parameters of pectin obtained with the use of enzyme preparations and without them it has been proved that the use of EP of amilolytic action leads to an increase in the pectin purity (uronide component) compared with control in 1,5 times. For the first time, the potato pectin complexing ability has been 
studied. The results of the studies showed that the potato pectin complexing ability is 310 $\mathrm{Pb}^{2+} \mathrm{mg} / \mathrm{g}$, which indicates the possibility of its use in health products as an enterosorbent.

It has been established that potato pectin has a high sorption capacity with respect to water, with the greatest hydration ability being possessed by pectin samples obtained using cellulase and $\alpha$-amylase enzymes. The amount of water sorbed with pectin is from 17 to $25 \%$. And the presence of a large number of mesopores makes it possible to recommend this pectin as an encapsulating agent for various low molecular weight substances.

\section{References}

1. Vincken J.-P., Schols H.A., Oomen R.J.F.J. (2003), If Homogalacturonan Were a Side Chain of Rhamnogalacturonan I. Implications for Cell Wall Architecture, Plant Physiology, 132, pp. 1781-1789.

2. Meyer A., Dam B., Helle N. (2009), Enzymatic solubilization of a pectinaceous dietary fiber fraction from potato pulp: Optimization of the fiber extraction process, Biochemical Engineering Journal, 43, pp.106-112.

3. Byg I., Diaz J., Øgendal L. H., Harholt J. (2012), Large-scale extraction of rhamnogalacturonan I from industrial potato waste, Food Chemistry, 131, pp.1207-1216.

4. Srichuwonga S., Fujiwara M., Wanga X., Seyama T. (2009), Simultaneous saccharification and fermentation (SSF) of very high gravity (VHG) potato mash for the production of ethanol, Biomass And Bioenergy, 33, pp. 890-898.

5. Lesiecki M., Białas W., Lewandowicz G. (2012) Enzymatic hydrolysis of potato pulp, Acta Scientiarum Polonorum, Technologia Alimentaria, 11(1),pp. 53-59.

6. Khalifa I., Barakat H., El-Mansy H., Soliman A. (2015), Physico-Chemical, Organolyptical and Microbiological Characteristics of Substituted Cupcake by Potato Processing Residues, Food And Nutrition Sciences, 6, pp. 83-100.

7. Tornberg E., Bengtsson H. (2011), Physicochemical characterization of fruit and vegetable fiber suspensions. Effect of homogenization, Journal Of Texture Studies, 42 (4), pp. 268 280.

8. Kaack K., Pedersen L., Laerke H.N., Meyer A. (2006), New improvement of texture and colour of wheat bread, European Food Research And Technology, 224 (2), pp. 199-207.

9. Spravochnyk khimyka 21, Available at: http://chem21.info/info/865339

10. Ravn H., Sørensen O.B., Meyer A. (2015), Time of harvest affects the yield of soluble polysaccharides extracted enzymatically from potato pulp, Food And Bioproducts Processing, 93, pp. 77-80.

11. Larsen P., Mathiasen M. (2005), Pat. WO 2005003178 A1.

12. Tobe J., Nakamura A., Takahashi T. (2014), Pat. EP 2014682 B1.

13. Danfeng H., Zhongshan X., Yanqiu Z., Wei D., Junfeng X.(2013), Pat. CN103265647 A.

14. Hrabovska O., Pastukh H., Moiseeva V., Miroshnyk V. (2015) Potato pectin:extract methods, physical and chemical properties and structural features, Ukrainian Food Journal, $4(1)$, pp. 7-13.

15. Donchenko L. and Firsov G. (2007), Pektin: osnovnye svojstva, proizvodstvo i primenenie, Moscow.

16. Srivastava P., Malviya R. (2011) Sources of pectin, extraction and its applications in pharmaceutical industry, Indian Journal of Natural Products and Resources, 2(1), pp. 10 18.

17. Nurdjanah S., Hook J., Paton J., Paterson J. (2013), Galacturonic Acid Content and Degree of Esterification of Pectin from Sweet Potato Starch Residue Detected Using ${ }^{13} \mathrm{C} \mathrm{CP} / \mathrm{MAS}$ Solid State NMR, European Journal of Food Research \& Review,3 (1), pp. 16-37. 
18. Ovodova R., Bushneva O., Shashkov A. (2000), Vydelenye i yssledovanye stroenyia polysakharydov iz smolevky obyknovennoi Silene Vulgaris. Byoorhanycheskaia khymyia, 26(9), pp. 686-692.

19. Ovodov Yu. (2009), Sovremennыe predstavlenyia o pektynovykh veshchestvakh. Byoorhanycheskaia khymyia, 35(3), pp. 293-310.

20. Khodaei N., Karboune S. (2013), Extraction and structural characterisation of rhamnogalacturonan I-type pectic polysaccharides from potato cell wall, Food Chemistry, 139, pp. 617-623.

21. Shuqian L. (2014), Pectin Extraction from Potato Residues by Different Methods of Salting out and Process Optimization, Advanced Materials Research, 926-930, pp. 174-181.

22. Liu Q., (2002), A Study of Enzymatic Hydrolysis of Starch in Potato Pulp, Journal of Food Science, 67(6), pp. 2113-2117.

23. Donchenko L. (2000), Tehnologija pektina i pektinoproduktov, Moscow.

24. Il'ina I.(2001), Nauchnye osnovy tehnologii modificirovannyh pektinov, RASHN, Krasnodar.

25. Kamnev A., Colina M., Rodriguez J. (1998), Comparative spectroscopic characterization of different pectins and their sources, Food Hydrocolloids, 12(3), pp. $263-271$.

26. Sedakova V., Gromova E. (2011), Issledovanie kachestvennogo sostava soputstvuyuschih saharov v pektine razlichnogo proishozhdeniya, Vestnik farmacii, 4 (54), 17-23.

27. Øbro J., Harholt J., Scheller H., Orfila C. (2004), Rhamnogalacturonan I in Solanum tuberosum tubers contains complex arabinogalactan structures, Phytochemistry, 65(10), pp. 1429-1438.

28. Hatko Z. (2008), Vliyanie pN protsessa osazhdeniya sveklovichnogo pektina na pokazateli ego kachestva. Izvestiya vuzov. Pischevaya tehnologiya Novye Tehnologii, 5, pp. 22-23.

29. Miheeva L., Try A. (2013), Vyidelenie pektina iz rastitelnogo syirya i izuchenie ego nekotoryih himicheskih svoystv, Vestnik VGU, Seriya: Himiya. Biologiya. Farmatsiya, 2, pp. 53-56.

30. Volovik L. (2011), Koloidna himija, Kyiv.

31. Kalinovska T., Obolkina V., Kyianytsia S. Doslidzhennia vmistu pektynovykh rechovyn napivfabrykativ z vynohradnykh vychavok ta vyznachennia yikh sorbtsiinykh vlastyvostei Available at: http://dspace.nuft.edu.ua/jspui/bitstream/123456789/14532/1/Sksgdvprnzvvtvisv.pdf

32. Carbinatto F., Castro A., Cury B. (2012), Physical properties of pectin-high amylose starch mixtures cross-linked with sodium trimetaphosphate, International Journal of Pharmaceutics, 423(2), pp. 281-288.

33. Hrabovska O., Pastukh H., Demenyuk O., Miroshnyk V., Halatenko T., Babii A. (2015), Kinetics of hydrolysis-extraction of pectin substences from the potato raw materials, Ukrainian Food Journal, 4(4), pp. 596-604. 